\title{
Government Public Relations in Turkey: Social Media Usage of Turkish Ministries in Relationship Building
}

\section{HatunBoztepeTaşkıran, Istanbul University, Turkey}

\begin{abstract}
Nowadays, developing long-term and positive relationships by government agencies with publics and managing the relationships strategically became very important. Social media provides a number of opportunities for government agencies in terms of building relationships and engaging with publics, developing relationships based on dialogue, ensuring the public participation in decision making and implementation. Taking advantage of the opportunities provided by the social media in terms of relationship building between government agencies and publics depends on full utilization of the interaction and participation supporting characteristics and the dialogic capacity that it provides. This study focused on revealing the case of benefiting from the opportunities offered by social media in order for ministries in Turkey to establish a relationship with publics and analyzed whether the social media is used for the purpose of one-way message transmission to publics or used accordingly with the nature of two-way symmetrical communication. Within the scope of study, corporate Facebook profiles and Twitter accounts of Turkish ministries were analyzed with a content analysis method. Findings were achieved through the analyzing social media accounts of Turkish ministries indicated that social media is used for one - way communication by the ministries. Moreover, it was seen that Turkish ministries do not take advantage of dialogical capacity of social media as a relationship building tool.
\end{abstract}

Keywords: Government Public Relations, Government Agencies, Relationship Building, Social Media 


\section{Introduction}

Changes and developments in terms of state administration in the foreground in recent years have increased the need for public relations by government agencies. With the transition to the paradigm of governance from the traditional administration approaches, power centrality has disappeared and a citizen-focused perspective started to dominate the state administration. In today's environment where the boundary between the governors and governed has completely become blurred and the administration power is shared among the layers that form the community, the obligation to get the support and approval of publics in decision-making and policy-making process of government agencies has been of great importance.

It is know that government agencies that exist in order to fulfil the public requirements are in an unbeatable situation in terms of the services they provide and that they are considered as unique. However, this advantage that government agencies hold does not mean that the need for developing positive relationships with publics disappear or can be ignored. On the contrary, it also draws attention to the fact that a strong connection exists between ensuring public interest which is the main goal of the discipline of public relations and the efforts of government public relations. In order to reveal the mission of providing the public interest by strategically managing the relationships and communication of government agencies with publics, it is necessary to identify the expectations of publics and to meet these expectations, to develop relationships based on dialogue between the parties of government public relations, to develop public awareness for various social issues or problems and achieving these goals is only possible by government public relations practices.

Public relations as a strategic management function focusing on building, maintaining, developing and managing relationships between organizations and publics with different characteristics cover the efforts in order to have positive and long-term relationships based on principles of mutual benefit, trust, understanding and goodwill. New media formed as a result of the recent developments in information and communication technologies made new tools that organizations can benefit during the building and managing relationships with publics available to the use of public relations. The communication medium formed of these new tools defined as social media brought significant opportunities on the agenda with its structure supporting the participation at the stages of establishing, developing and maintaining 
relationships between organizations and publics and supporting interaction and dialogue between the parties of the relationship.

This study aims to demonstrate the benefiting of the line ministries in Turkey which are the main government agencies in need of building and developing positive relationships with publics from social media in relationship building. In addition, it aims to determine whether the dialogic capacity provided by the social media in creating dialogue-based relationships with publics is fully used by the ministries by analyzing their social media accounts.

\section{Government Public Relations from the Governance Perspective}

It can be said that government agencies feel the need to have positive relationship with the governed target audience. However, transformation in the form of transition from the approach of management in which power is collected under one authority to a type of management in which the power is shared by all actors forming the society carried these needs of the government agencies to the top level.

Concept of governance in relation with changes occurring in the core of the state administration is different from the decisions taken in parliament by the elected deputies and traditional management model implemented by public administration authorities; and governance points out the changes in both the creation and implementation of policies and in the actors in style of political governance. Governance expresses the cooperation among the actors in the state administration and working together harmoniously (Treib, Bähr\& Falkner, 2007; Jordan \&Schout, 2006; Frahm\& Martin, 2009; Kooiman, 2003). Governance approach considers the target audience that consists of the governed, which are the citizens, one of the actors that holds shares in the state administration and therefore, it emphasizes the strategic administration of relationships between government agencies and publics by government public relations.

Governance did not only bring the need to revise the relationships between government agencies and publics on the agenda but also attributed even greater importance to positive relationships to be developed. Government public relations as an important field of expertise and application of public relations have aroused attention as it provides important contributions to the government agencies with strategies and applications focusing on the management in line with the two-way symmetrical communication based on the principles of 
dialogue and interaction as required for relationships between government agencies and publics by contemporary approach of public relations.

The purpose of public relations practice is to establish two way communication seeking common ground or areas of mutual interest and to establish understanding based on truth, knowledge and full information (Black, 1989: 1). Depending on the main purpose of public relations discipline, government public relations practices help government agencies to find a common ground with their citizens. In this way, government public relations makes a significant contribution to achieve corporate objectives and guarantee the occurrence of public interest.

Government public relations plays a crucial role in keeping the public informed about issues, problems, and actions at all levels of government. Government public information officers seek citizen approval of government programs, help explain what citizens want from the government, strive to make government responsive to citizens' wishes, and attempt to understand and affect public opinion (Baskin et al., 1992: 392). Government public relations efforts in compliance with governance paradigm should focus on building positive and longterm relationships between government agencies and their publics. Therefore these efforts will be able to serve the purpose of building mutual understanding, trust and goodwill between government agencies and their publics based on dialogical communication and maintaining positive relationships.

\section{Social Media and Relationship Building}

Relational paradigm which has come into prominence in public relations literature in the recent years pointed out a new definition of public relations concept. With relationship management approach, a consensus has emerged that public relations is a discipline that focuses on the strategic management of relationships between organizations and publics. (Bruning\&Ledingham, 2000a; Jo, 2006; Grunig, 2006; Jo, Hon \& Brunner, 2004; Watson \& Noble, 2005; Bruning\&Ledingham, 2000b).With relational paradigm, public relations has started to be defined as a management function that identifies, establishes, and maintains mutually beneficial relationships between an organization and the various publics on whom its success or failure depends (Cutlip et al., 2006: 6). Also concept of relationship has drawn attention in the public relations discipline. 
Strategies and practices of relationship management focus on the aim of having positive, long-term relationships based on the principles of mutual benefit, trust, understanding, goodwill and the organizations who want to achieve this goal successfully should adapt to the principles of two-way symmetrical communication.

If the purpose of public relations is to build relationships between organizations and publics, however, then corporations must conceptualize and measure both communication processes and outcomes as two way by looking for effects on management as well as on publics. Corporations can build relationships more effectively if they build symmetrical ones, which benefit both organizations and publics, than if they build asymmetrical ones that benefit only the organization (Grunig\& Huang, 2000: 27). Using a symmetrical model results in more positive, long-term relationships with an organization's publics, helping the organization achieve its goals (Wise, 2007: 154).

Demonstration of the communication process based on two-way symmetrical communication and balance of dialogue and mutual power in the organization-public relationships is supported in the relationship management that conceptualizes the organizations and publics as parties of the relationship with equal power. Efforts in terms of public relations through the implementation of two-way symmetrical model do not only allow achieving the goal of establishing relationships with publics but also allows the realization of the dialogic approach of public relations. The data obtained in the research by Bruning, Dials and Shirka (2008) in order to reveal the importance of the use of dialogue in the relationship between organizations and publics points out that organizations have the opportunity to establish the best relationships by dialogic process and highlights that the dialogic approach requires to be engaged with publics in the communication process.

The emergence of the Internet and the World Wide Web opened up new opportunities for dialog and relationship - building between organizations and their publics (Avidar, 2013: 440). Two way communication and the theory of symmetry can be neatly related to the characteristics of a new medium, such as interactivity or reciprocal performance (Jo \& Kim, 2003: 200). Internet based communication tools which have emerged as a consequence of development on information and communication technologies have put new tools into service 
of public relations such as corporate web sites and social media environments. These new tools especially social media environments have a huge potential to build relationships based on dialogue between corporations and their publics.

Social media providing opportunities in order for organizations to build relationships with publics and to be in dialogue arouses attentions in terms of relationship management with the characteristics of participating and interacting. Social media ensures an environment that allows organizations to use of capacity allowing to receive feedback from publics, to understand the needs and expectations of them, to be engaged with conversation and dialogue rather than one - way message transmission which develops the relationships between the organizations and publics (Lovejoy, Waters, \& Saxton, 2012; Smith, 2012; Briones, Kuch, Liu \&Jin, 2011). Social media is based on a dialogue in organization - public relations and also enable two way communication and interactivity due to their structure. For this reason social media should be used and utilized in relationship management processes.

The organizations that would like to establish relationships with publics via social media should fully use the capacity in terms of realizing the dialogic public relations approach of the social media; it is important to benefit from the social media for the purpose of establishing dialogue rather than one - way transfer of corporate context and messages.

\section{Government Agencies and Social Media Usage}

Social media among web 2.0 technology features accommodates a huge potential for public institutions that wish to remain in contact and establish relationship with the target audience formed of citizens (McNutt, 2014). Today, the use of various social media environments by government agencies is increased in order to provide the interaction with the governed (Agostino, 2013). Social media comes to the front in terms of ensuring the connection and interaction of state administration with publics as well as publics to be participating by providing the opinions and suggestions, taking administrative decisions and ensuring the public participation in the process of policy making.

Nevertheless, social media-based public engagement is an uncharted territory and government agencies generally lack experience and knowledge about implementing social media (Lee \&Kwak, 2012: 492). Ensuring the participation of publics in the decisions and policies with 
their opinions and suggestions, shaping the decisions and policies in line with the expectations and requirements of publics, and creation of a common ground on the reconciliation axis with publics is directly related to the power in order to build positive relationships between government agencies and publics. Therefore, social media should be used in accordance with symmetrical communication principles. It can be said that government agencies which use social media environments as one - way communication tools do not take advantage of dialogical capacity of social media adequately.

\section{Methodology}

Social media allows government agencies to communicate with publics very fast and comes to the foreground with the characteristic of empowering the interaction with dialogue. This study aims to reveal whether the social media is used by the line ministries of Turkey in relationship building and identify whether the ministries fully benefit from the dialogic capacity provided by the social media in establishing relationships based on dialogue. Research to be performed with regard to these goals aims to answer the following questions:

RQ1. Do the line ministries in Turkey have accounts in the social media?

RQ2. Are social media accounts of ministries directed on the corporate web pages?

RQ3. Do the ministries use social media for the purposes of one - way transfer of messages or two-way symmetrical communication?

Social media accounts of ministries as the main government agencies have been analyzed with content analysis method for the detection of the case of use of social media for the purpose of establishing relationships with publics in terms of government public relations. At the stage of selection of the social media tools to be analyzed, the most used social media environment in Turkey are taken into account; as $93 \%$ of the internet users in Turkey uses Facebook and $72 \%$ of them uses Twitter (We Are Social's Report, 2014), an analysis has been carried out on these two social media tools that came in the front.

Ministries whose social media accounts have been analyzed are listed below: Ministry of Justice, Ministry of Internal Affairs, Ministry of Finance, Ministry of Environment and Urban Planning, Ministry of Transport, Maritime Affairs and Communications, Ministry of Labour and Social Security, Ministry of Energy and Natural Resources, Ministry of Forestry and Water Affairs, Ministry for EU Affairs, Ministry of Youth and Sports, Ministry of 
Development, Ministry of National Defence, Ministry of Foreign Affairs, Ministry of Education, Ministry of Health, Ministry of Food, Agriculture and Livestock, Ministry of Science, Industry and Technology, Ministry of Culture and Tourism, Ministry of Family and Social Policies, Ministry of Economy, Ministry of Customs and Commerce (E - Government, 2015).

In accordance with the research, availability of directing primarily from corporate web pages of the ministries to their social media accounts is checked which is followed by checking the availability of their Facebook and Twitter accounts. An analysis has been carried out in line with the established communication with publics on the social media in the following period of the research. The social media contents of the ministries have been evaluated for the purposes of informing the various corporate decisions and activities of publics for one-way message transmission and to provide one-way communication with publics and to support dialogue; a detailed analysis has been carried out in order to find out data to see whether the ministries in Turkey fully benefited from the capacity offered by social media tools to build relationships with publics based on dialogue.

\section{Corporate Web Page Analysis}

Before analyzing social media accounts of the ministries, it has been investigated whether Twitter and Facebook accounts are directed from the corporate web pages. It attracts attention that social media accounts of half of the ministries are directed over their corporate web pages $(n=10,47.6 \%)$, but it has been found out that other ministries $(n=11,52.4 \%)$ do not have such a direction over their corporate web pages.

Table 1: Direction from corporate web pages to corporate social media accounts of the ministries

\begin{tabular}{|l|c|c|c|c|}
\hline \multirow{2}{*}{} & \multicolumn{2}{|c|}{ Exists } & \multicolumn{2}{c|}{ Not exist } \\
\cline { 2 - 5 } & f & $\%$ & f & $\%$ \\
\hline $\begin{array}{l}\text { Direction from corporate web pages to social } \\
\text { media accounts }\end{array}$ & 10 & $47,6 \%$ & 11 & $52,4 \%$ \\
\hline
\end{tabular}




\section{Social Media Analysis}

Facebook and Twitter accounts of ministries and the content they shared on the accounts have been analyzed to check whether they are in accordance with the one-way communication or two-way communication within the period of six months between September 2014 and March 2015 and whether they hold the features of providing possibility to form interaction and develop dialogue with publics. All content shared on Twitter and Facebook by the ministries are coded for the purposes of focusing on the purposes of being towards one-way communication or realizing two-way communication, forming interaction and developing dialogue.

It has been found out in the investigations on Twitter accounts of the ministries that only 2 $(9.5 \%)$ of 21 line ministries do not have Twitter accounts.

Table 2: Possession of corporate Twitter Accounts

\begin{tabular}{|l|c|c|c|c|}
\hline \multirow{2}{*}{} & \multicolumn{2}{|c|}{ Yes } & \multicolumn{2}{c|}{ No } \\
\cline { 2 - 5 } & f & $\%$ & f & $\%$ \\
\hline $\begin{array}{l}\text { Possession of corporate Twitter accounts } \\
\text { of ministries }\end{array}$ & 19 & $90,5 \%$ & 2 & $9,5 \%$ \\
\hline
\end{tabular}

From the perspective of signing in Twitter, it has been shown that the first ministry that created an account on Twitter in 2009 was Ministry of Foreign Affairs, Ministry of Science, Industry and Technology created an account in 2010, and other ministries joined Twitter mostly in $2011(n=4)$ and $2012(n=11)$. There is no information available on the signing in of two ministries to Twitter.

57,215 tweets posted by ministries until 9th March 2015 have been analyzed in terms of accordance with the nature of one-way or two-way communication and it has been identified that all tweets serve for the realization of one-way communication as in public information model. Even though some of the ministries use their Twitter accounts actively, it has been found out that all applications on Twitter carry the purpose of informing publics about the decisions taken by the ministries and activities held of future activities. It has also been found out in line with the analysis whether the ministries refollow a large number of their followers and also whether followers reply to the content shared by ministries. Publics can only 
retweetthe tweets created by the ministry or add the tweets of ministry to favourites. Any feedback by publics has not been seen for the tweets created by the ministries. The shared content on Twitter with an @ mark can be expressed as a demonstration of interaction and tweets with this mark truly is for and addresses specific members (Etter, 2013: 607). It has been highlighted that this mark that can be qualified as a proof of interaction was not observed on Twitter accounts of the ministries. It has been observed that some tweets posted with@ mark address only ministers or senior government officials.

Sharing of an e-mail account with the users of social media on Twitter account by Ministry of Health specific for social media is a point that renders this ministry different from the other ministries. It has been found with the analysis of the Facebook accounts of ministries that more than half of the ministries created accounts on Facebook $(n=11,52,4 \%)$. The number of ministries that has a fan page on Facebook is $6(28,6 \%)$ whereas the number of community page of ministries formed by the staff is 1 . Additionally, three ministries cannot be found on Facebook.

Table 3: Forms of existing on Facebook of ministries

\begin{tabular}{|l|c|c|c|c|}
\hline \multirow{2}{*}{} & \multicolumn{2}{|c|}{ Yes } & \multicolumn{2}{c|}{ No } \\
\cline { 2 - 5 } & f & f & f & $\%$ \\
\hline $\begin{array}{l}\text { Possession of a corporate Facebook } \\
\text { profile }\end{array}$ & 11 & $52,4 \%$ & 10 & $47,6 \%$ \\
\hline Possession of a fan page & 6 & $28,6 \%$ & 15 & $71,4 \%$ \\
\hline Possession of a community page & 1 & $4,7 \%$ & 20 & $95,3 \%$ \\
\hline
\end{tabular}

It has been determined in line with the analysis of the shared content through the Facebook accounts of ministries that the reply of publics is available through the buttons of like, comment and share to the shared content. However, it has been emphasized that the comments made under the contents are not replied by the ministries and any explanations are not available which shows that these comments are evaluated. It has been found out that all content shared on Facebook with publics by ministries carry the purpose of informing publics about the decisions taken by ministries and activities held of future activities. 


\section{Conclusion and Discussion}

Government public relations focuses on the strategic management of relationships of government agencies with publics formed of citizens; government public relations practices shaped in line with the two-way symmetrical communication based on dialogue and interaction make high contributions to the government agencies by enabling the establishment of good relationships.

Social media as an internet-based application as a result of the developments in information and communication technologies provides countless opportunities for the stages of establishment, development and maintenance of relationships between government agencies and publics and allows the formation of dialogue between the parties of relationship, the enabling of interaction and the presentation of participation. Limiting the communication performed by government agencies with publics on social media with a narrow purpose such as informing publics about the decisions and activities means not using the dialogic capacity provided by the environment of social media adequately.

Social media interaction with its structure that supports dialogue and participation should go beyond being a tool on which one-way message transmission only from government agencies to citizens is performed and should be used as environment on which citizens deliver their opinions on public decisions, practices and policies to the government agencies. The government agencies should shape their practices in line with the opinions, suggestions and expectations of publics delivered through the social media.

As found in other studies (Park \&Reber, 2008; Bortree\& Seltzer, 2009; Rybalko\& Seltzer, 2010) that the dialogic potential of the corporate web pages and the social media environments formed with new communication technologies has not been fully used and the opportunities of interactivity and dialogue developing provided in building and managing organization - public relationships, similar findings are observed in this study.

In the research carried out by analyzing the social media accounts of the line ministries in Turkey which form part of the main government agencies, findings were observed on the use of social media by the ministries with the aim of one-way message transmission rather than realizing the two-way communication with publics. It has been detected that the ministries 
benefited from social media in informing publics rather than benefiting from the characteristic of interactivity and dialogic capacity provided by the social media during the process of building relationships.

As mentioned by Ministry of Justice on Twitter, using Twitter and Facebook as an internetbased tool in which official announcements of the ministry are made can be interpreted as not fully using the capacity provided by social media environments at the stage of establishing positive relationships based of dialogue and interaction between the government agencies and publics.

A practice on requiring the opinions of publics about various topics during the analysis of Facebook pages of the ministries is very important as the characteristic of social media that allows the two-way communication and interaction with publics is very useful. It has been remarked that Ministry of Forestry and Water Affairs shared a post on the social media account where publics was invited for an online voting on the logo of Desertification Conference to be held in October 2015 and that it directs publics to corporate web page for voting. This type of content arouses attention to enable decision and participation of publics and taking opinions and suggestions of them. However, enabling the interaction between publics and the government agencies by the social media should not be limited with this level. It should be underlined that the replies created by publics for the content shared on the social media should be taken into account and the corporate replies should be constituted by ministries.

\section{Limitations}

In current study, use of social media and benefiting from the dialogic capacity of social media environments in relationship building for government public relations efforts analyzed only by examining the social media accounts of ministries. This was main limitation of study. Benefiting from the social media for the purpose of relationship building between the other type of public institutions, such as municipalities, and publics or detecting the cases of using the social media for the purpose of two-way communication, revealing the cases of using the dialogic capacity provided by the social media would provide more detailed information on the use of social media in terms of government public relations practices in Turkey. 


\section{Future Research}

In the future researches it can be recommended to study on comparison of use of social media in relationship building between private sector institutions, non-governmental organizations and government agencies. It will be possible to access the data in order to find out how the interaction, features of participation and capacity of dialogue provided by social media should be used optimally with such a sectoral comparison. In addition, it can be suggested to carry out studies in order to find out the structure to establish or develop the existing relationships based on dialogue with publics by the content shared on social media by the government agencies. Identification of the perceptions and expectations of publics from the social media practices by government agencies is also of necessity in terms of meeting the needs of the other party of the relationship. 


\section{References}

Agostino, D. (2013). Using Social Media to Engage Citizens: A Study of Italian Municipalities. Public Relations Review, 39, 232 - 234.

Avidar, R. (2013). The Responsiveness Pyramid: Embedding Responsiveness and Interactivity into Public Relations Theory. Public Relations Review, 39, 440 - 450.

Baskin, O., Aronoff, C. \& Lattimore, D. (1997). Public Relations The Profession and The Practice. $4^{\text {th }}$ edition. Boston: McGraw Hill.

Black, S. (1989). Introduction To Public Relations. $2^{\text {nd }}$ edition. London: The Modino Press.

Bortree, D. S. \& Seltzer, T. (2009). Dialogic Strategies and Outcomes: An Analysis of Environmental Advocacy Groups’ Facebook Profiles. Public Relations Review, 35, $317-319$.

Briones, R. L., Kuch, B., Liu, B. F. \&Jin, Y. (2011). Keeping Up With the Digital Age: How the American Red Cross Use Social Media To Build Relationships. Public Relations Review, 37, $37-43$.

Bruning, S. D., Dials, M. \&Shirka, A. (2008). Using Dialogue To Build Organization - Public Relationships Engage Publics and Positively Affect Organizational Outcomes. Public Relations Review, 24, 25 - 31.

Bruning, S. D. \&Ledingham, J. A. (2000a). Perceptions of Relationships and Evaluations of Satisfaction: An Exploration of Interaction. Public Relations Review, 26 (1), 85 - 95. Bruning, S. D. \&Ledingham, J. A. (2000b). Organization and Key Public Relationships: Testing the Influence of the Relationship Dimensions in a Business - To - Business Context. In J. A. Ledingham\& S. D. Bruning (Eds.). Public Relations As Relationship Management A Relational Approach To the Study and Practice of Public Relations (pp. 159 - 173). Mahwah: Lawrence Erlbaum Associates.

Cutlip, S. M., Center, A. H. \& Broom, G. M. (2006).Effective Public Relations. $9^{\text {th }}$ edition. New Jersey: Pearson Education Inc.

E - government (2015). Retrieved from http://www.turkiye.gov.tr/kurumlar

Etter, M. (2013). Reasons For Low Levels of Interactivity (Non-) Interactive CSR Communication in Twitter. Public Relations Review, 39, 606 - 608.

Frahm K. A. \& Martin, L. L. (2009). From Government To Governance: Implications For Social Work Administration. Administration in Social Work, 33, 407 - 422.

Grunig, J. E. (2006). After 50 years: The Value and Values of Public Relations. The Institute for Public Relations $45^{\text {th }}$ Annual Distinguished Lecture, New York, $1-7$. 
Grunig, J. E. \&Huan, Y. H. (2000). From Organizational Effectiveness To Relationship Indicators: Antecendents of Relationships, Public Relations Strategies, and Relationship Outcomes”. In J. A. Ledingham\& S. D. Bruning (Eds.). Public Relations As Relationship Management A Relational Approach To the Study and Practice of Public Relations (pp. 23 - 53). Mahwah: Lawrence Erlbaum Associates.

Jo, S. (2006). Measurement of Organization - Public Relationships: Validation of Measurement Using A Manufacturer - Retailer Relationship. Journal of Public Relations Research, 18 (3), 225 - 248.

Jo, S., Hon, L. C. \& Brunner, B. R. (2004). Organization - Public Relationships:

Measurement Validation in A University Setting. Journal of Communication Management, 9 (1), $14-27$.

Jo, s. \& Kim, Y. (2003). The Effect of Web Characteristics on Relationship Building. Journal of Public Relations Research, 15 (3), 199 - 223.

Jordan, A. \&Schout, A. (2006). The Coordination of the European Union: Exploring the Capacities of Networked Governance. Oxford: Oxford University Press.

Kooiman, J. (2003). Governing As Governance. London: Sage Publications.

Lee, G. \&Kwak, Y. H. (2012). An Open Government Maturity Model For Social Media Based Public Engagement. Government Information Quarterly, 29, 492 - 503.

Lovejoy, K., Waters, R. D. \& Saxton G. D. (2012). Engaging Stakeholders Through Twitter: How Nonprofit Organizations Are Getting More Out of 140 Characters or Less. Public Relations Review, 48, $313-318$.

McNutt, K. (2014). Public Engagement in the Web 2.0 Era: Social Collaborative Technologies in A Public Sector Context. Canadian Public Administration, 57 (1), 49 -70 .

Park, H. \&Reber, B. H. (2008). Relationship Building and the Use of Web Sites: How Fortune 500 Corporations Use Their Web Sites To Build Relationships. Public Relations Review, 34, 409 - 411.

Rybalko, S. \& Seltzer, T. (2010). Dialogic Communication in 140 Character or Less: How Fortune 500 Companies Engage Stakeholders Using Twitter. Public Relations Review, $36,336-341$.

Smith, B. G. (2012). Public Relations Identity and The Stakeholder - Organization Relationship: A Revised Theoretical Position For Public Relations Scholarship. Public Relations Review, 38, 838 - 845 . 
Treib, O., Holger, B. \& Gerda, F. (2007). Modes of governance: Towards A Conceptual Clarification. Journal of European Public Policy. 14 (1), 1 - 20.

Watson, T. \& Noble, P. (2005).Evaluating Public Relations. London: Kogan Page.

We Are Social Report (2014). Retrieved from http://wearesocial.net/tag/turkey/

Wise, K. \& APR (2007). The Organization and Implementation of Relationship

Management.Health Marketing Quarterly. 24 (3 - 4), 151 - 166. 